Article

\title{
Emotion Regulation and Employability: The Mediational Role of Ambition and a Protean Career among Unemployed People
}

\author{
Chiara Panari ${ }^{1}$, Michela Tonelli ${ }^{2, *}$ and Greta Mazzetti ${ }^{3}$ (D) \\ 1 Department of Economics and Management, University of Parma, Via J. Kennedy, 6, 43125 Parma, Italy; \\ chiara.panari@unipr.it \\ 2 Department of Humanities, Social Sciences and Cultural Industries, University of Parma, \\ Via M. D'Azeglio, 85, 43125 Parma, Italy \\ 3 Department of Education Studies, University of Bologna, Via Filippo Re, 6, 40126 Bologna, Italy; \\ greta.mazzetti3@unibo.it \\ * Correspondence: tonelli.mich@gmail.com
}

Received: 1 October 2020; Accepted: 2 November 2020; Published: 11 November 2020

\begin{abstract}
Literature on job searching suggests that emotion regulation has an impact on employability, but this relationship is far from being explained; furthermore, most of the studies have been conducted among students or workers. The aim of the current study was to investigate the relationship between emotion regulation and employability among unemployed people, analyzing the role of ambition and protean career orientation as possible factors in such a relationship. Participants were 228 unemployed subjects who had requested individual counselling for job searching; data were collected by means of a self-report questionnaire. Results confirmed that emotion regulation is related to employability, both through a direct relationship and through an indirect effect of ambition and protean career orientation.
\end{abstract}

Keywords: emotion regulation; perceived employability; ambition; protean career; unemployment

\section{Introduction}

Unemployment has negative consequences and produces costs for individuals, societies, and economies. Examples include limited economic growth potential, scarce economic resources, and social deprivation [1,2]. The individual costs of unemployment involve loss of income, social relations, and status, as well as the physical and psychological well-being of individuals and their families [3,4].

Most of the psychological research on unemployment has been dedicated to investigating the effects of job loss, specifically the negative effects on well-being, such as physical complaints, depression, suicide, and mortality [3-5]. Unemployment determines repeated exposure to stress, along with deteriorated emotional self-regulation, and decreases the ability to cope with the negative consequences of job loss. The likelihood of finding new employment drops as well, for a variety of reasons, from lack of job skills and knowledge to labour market requirements [1].

There are many examples of government interventions aimed at helping unemployed individuals regain employment or cope with the stressful effects of unemployment [6,7]. However, none of those interventions have focused on improving the emotional or psychological competencies of unemployed adults. Emotional competencies are defined as the interrelated sets of behaviors that individuals use to recognize and manage their own emotions and those of others [1]. In the last few decades, several Italian local governments have promoted the so-called active policies of labour which, as opposed to passive policies (i.e., economic subsidies), aim to develop employability through requalification, counselling, and skills assessment courses. Most of the subjects who participated in such courses had asked for the 
acquisition of practical skills, rather than the implementation of personal skills [8]. These programs usually teach about job search skills (e.g., interview skills, how to write a curriculum vitae, or how to use a computer) or other job-related skills (technical skills, communication, or problem solving), with the purpose of helping participants successfully find employment and increase their employability [9].

Learning outcomes are important for employability, but an individual's well-being is also essential for finding a job and, if necessary, creating work [10], which is in turn crucial to labour market prospects [11,12].

Unemployment literature $[13,14]$ shows that a combination of training in job search skills and enhancing one's coping strategies can have a positive effect on people. Regardless of the specific type of intervention, these actions have a positive impact on unemployed participants, increasing not only their employability, but also their physical and psychological well-being [1].

Research indicates that one's employability perception and job search intensity-as crucial factors in regaining employment and developing employment capacity-are important in mitigating the negative effects of job loss. Whereas employability has become an important research topic, its role as potential moderator of the outcomes of insecurity or job loss has received little attention [8].

Since employability depends on psychological factors (such as awareness of skills, abilities, and knowledge), enhancing people's emotional competencies might help them to have a better perception of their employability prospects [1].

Although previous work [15] suggested that emotion regulation might be a determinant of opportunities to gain employment and obtain better career outcomes, there is little research examining the potential underlying the mechanisms in this association [16]. Furthermore, most of the research on employability has involved workers or students, while less is known about unemployed people.

\subsection{Emotional Regulation and Perceived Employability}

As suggested by Wang [17], emotion regulation is an important perspective from which to investigate the job search process. Emotion regulation is defined by Brockman, Ciarrochi, Parker, and Kashdan [18] as "the process by which individuals modify their emotions, their response to the emotions or the situations that elicit emotions in order to respond appropriately to environmental demands." In particular, two strategies of emotion regulation were identified in current literature: the cognitive reappraisal strategy, which involves reconstructing the meaning of an emotion-eliciting situation in a way that changes its emotional impact [19], and the expressive suppression strategy, which involves inhibiting ongoing emotionally expressive behaviour [20,21].

Cognitive reappraisal seems to be more effective than expressive suppression in managing negative emotions and improving life satisfaction [22]. Furthermore, expressive suppression may exacerbate anxiety reactions [23].

Further evidence pointed at emotion regulation as a protective factor that reduces adverse reaction to stress in the workplace [16]. For example, employees with high levels of emotion regulation cope more effectively with negative job stressors $[24,25]$. In turn, functional emotion regulation is associated with positive job attitudes, including higher job satisfaction and lower burnout symptoms [26]. In the understanding of employees' emotional perspectives in the workplace, there is no evidence supporting their implications in the job search process. In line with previous research [16], understanding what personal variables that could influence job searching may help career counsellors to identify potential risks related to negative career outcomes.

Research conducted by Peláez-Fernández, Rey, and Extremera [27] revealed that emotional abilities act as a personal protective factor that allows unemployed people to reframe threatening situations often associated with psychological maladjustment, thereby helping unemployed individuals overcome employment difficulties more efficiently.

Regarding employment status, the ability to regulate one's emotions contributes to one's capacity to achieve one's goal of finding a job [28]. Thus, emotion regulation has become one of the best ways to achieve success in reemployment and employability, because it acts as a performance facilitator that 
might improve job search activities [29,30]. For example, Callea et al. [31] shared that individuals with a high ability to express unpleasant emotions and to adapt to different situations tend to receive better interview feedback and outcomes. In line with these results, emotion regulation strategy mediates the relationship between goal orientation and job search [17].

Emotion regulation is related to positive job search outcomes, as well as to the subjective perception of the possibility of finding a job. For instance, employees who perceive themselves as having high control over their emotions also perceive themselves as more employable, which facilitates their job search process and subsequent job outcomes [32]. According to Hodzik and colleagues [1], emotion regulation is linked to the subjective perception of employability, which becomes an important resource in coping with the negative effects of job loss. The construct of perceived employability was introduced by Bernston et al. [33] and refers to the subjective perception of the possibility of maintaining one's current job and future opportunities to secure equal or better employment [33,34]. Employability plays a central role in the valuation of new career opportunities that fit with one's values and goals and should be important to those seeking to manage their own careers. For instance, De Vos and Soens [35] found a strong association between perceived employability and career self-management behaviours, and De Vos et al. [11] found that perceptions of employability and career self-management are associated with increased career mobility.

Considering emerging trends in the labour market and changes in career development, increasing employability is an important task for unemployed people and those who are looking for a new job, because their career might depend on their perceived employability [36]. Employability is the result of the combination of knowledge, practical skills, and ability to change those facets and to adapt to new circumstances [37]. For unemployed people, this pro-active characteristic of employability becomes a crucial resource in coping with the negative effects of job loss. Individuals perceiving themselves as more employable also evaluate unemployment as less harmful and can more easily tackle the stressful consequences of job loss [1]. Furthermore, employability is related to better and more proactive job search behaviours and, consequently, to favorable job search outcomes [37].

One's subjective perception of the difficulties or obstacles that one could encounter during the job-seeking process is also closely related to one's perceived employability [38]. The struggle of an individual in believing in his/her chances of finding employment, while not consistent with facts, can play a specific reactive predictive role [39].

Among the different taxonomies of factors affecting an individual's employability, central roles are attributed to work centrality, values and goals; availability, adaptability, and difficulties in finding a job; attitudes and fears about the unemployment situation and the search for a new job $[38,40]$.

Previous results stressed that emotion regulation has an impact on employability [1], but this relationship is far from being fully explained. Thus, the aim of the current study is to investigate the relationship between emotion regulation and employability among unemployed people, analyzing possible factors involved.

\subsection{Ambition, Protean Career Orientation and Employability}

In order to analyze individuals' perceived employability and adopted job search strategies, it becomes crucial to consider the role that individuals attribute to their professional life: work centrality, job values, and work goals are essential for active job search behaviours [38,41]. Although most of the research has been performed among workers and students, literature suggests that working towards individual self-realisation and goal clarity is important, as it plays a central role in the activation of proactive behaviours [16].

While most studies is conducted on workers and less is known about unemployed people, research confirms that goal clarity, ambition [42,43], a protean career orientation [44-46] and proactive behaviours [16] should be considered antecedents of perceived employability. However, a detailed explanation on this process is still lacking. 
Rothwell [47] introduced the concept of ambition in his studies focusing on students' employability as a proxy for the perception of future career success, and defined the concept as one's willingness and commitment to achieve one's professional goals, considering the importance attributed to career for personal self-realization. Ambitious people tend to entertain plans and goals for their professional future, get promoted and are intent on building a "nice" career [48]. Otto and colleagues [49] defined career ambition as an essential predictor of successful career development, consisting of the motivation to actively further one's career by having a strong focus on one's professional life and career (career orientation), combined with high motivation to excel (achievement motivation). Achievement motivation entails aiming for high performance by optimizing and engaging in vocational goals, while career orientation describes an individual's aspiration to attain those vocational goals, even if great effort is needed.

As previously mentioned, Rothwell [47] considered ambition as a concept closely linked to employability. Along the same line, ambition can positively affect the level of self-perceived employability [42]. In 2018, Ćurić Dražić and colleagues [43] investigated the relationships among locus of control, ambition, and self-perceived employability, and found that career ambition acted as a mediator in the relationship between locus of control and employability, and that ambition was strongly and positively related to employability. According to these authors, ambition could be regarded as a mechanism that put values on outcomes, connecting beliefs about personal efforts that stemmed from the internal locus of control to career success.

Individuals feeling aware of their own abilities and with professional goals are expected to go a step further and act [16]. Therefore, proactivity, which is defined as the stable inclination to take personal initiative in diverse situations, might also be relevant to adaptive and positive career outcomes among job seekers [50]. Empirical literature suggests that proactive people show more initiative [51-53], identify opportunities [1], and experience higher intrinsic motivation [54] during the job search process.

The first description of a protean career orientation referred to an individual's attitude in which career choices were personal and underlay the search for self-fulfilment [55]. In contrast to the traditional concept of career as growth within the same organisation, a protean career is conceived as being self-directed [56]: the employees identify their own individual career goals, regardless of organisational provisions [57]. Protean career orientation is value-driven, in the sense that personal internal values provide the guidance and measure of success for the individual's career [55]. Furthermore, the individual values that drive careers are aimed at pursuing meaningful career goals guided by personal aspirations [46]. Protean people are likely to look for job opportunities that satisfy life needs and not just professional or organisational needs [58], thus giving the term "career" a strong association with self-realization. Exploring the role of behavioural skills as predictors of protean career guidance is particularly salient, as they can be enhanced by educational institutions [59], with relevant implications when training individuals for the current labour market.

People with a high level of protean career orientation tend to develop individual perceptions of being employable and to be more constant in their job search despite adversity [46]. Furthermore, personal characteristics associated with a protean career orientation make candidates highly attractive to potential employers [60].

Recent studies investigating the relationship between a protean career orientation and perceived employability $[44,46]$ found a positive relationship there. People with a strong protean career orientation tend to seek opportunities to improve the knowledge and practical skills that are required in the current market, thereby enhancing their employability. A protean career orientation may also lead individuals to regularly scan the environment, in order to have more chances of identifying opportunities that meet their expectations [46].

\subsection{Relationship Among Emotional Regulation, Ambition and Protean Career Orientation}

As reported by Urquijo et al. [16], proactive people are more willing to cope with the difficulties of job searching and to persevere despite the stress of challenging workplace circumstances. Furthermore, 
previous findings suggested that emotions could be properly applied to guide appropriate behaviour and that thinking leads individuals to take initiative [61]. The limited literature on the impact of emotional intelligence on proactivity $[62,63]$ shows that individuals with higher levels of emotional competency are more tolerant of stress and are characterised by positive affectivity, which, in fact, may impact proactivity [16]; furthermore, for unemployed people, this proactive characteristic of employability makes it an important resource for coping with the negative effects of job loss [1]. Regarding this, Urquijo et al. [16] reported that people with high levels of emotion regulation tend to use more useful career strategies, which facilitates their job search process and likelihood of being hired. In addition, proactive people report high levels of initiative, identify more job opportunities, and are guided by intrinsic motivations when they are engaged in the job search process. It could be assumed that, in job searching, emotion regulation is related to the concept of ambition, defined as one's personal investment in identifying and achieving one's professional goals [47].

This reasoning is consistent with the results suggesting that there is a significant positive relationship between students' emotional intelligence and their level of ambition and career success [64]. The above-mentioned authors also reported a positive significant association between emotional intelligence and the level of commitment and ambition found in university students. Hence, a high level of commitment will have an impact on students' ambition and success, and students who feel that they have received high-quality learning during their academic career will have higher levels of ambition and satisfaction and will look forward to a brighter future.

Regarding ambition and career exploration, Norizan and Siti-Rohaida [65] indicated that both dimensions of a protean career orientation had a positive influence on career exploration. To be specific, in the authors' opinion, focusing on career goals leads one to engage in behaviours that will help with the achievement of one's personal goals, and career goal development has a positive influence on one's psychological well-being.

\subsection{Aims and Hypotheses}

Based on literature and on findings previously discussed, the following hypotheses were formulated:

Hypothesis 1 (H1). Perceived employability is positively associated with emotion regulation, ambition, and protean career orientation.

Hypothesis 2 (H2). Emotion regulation is related to employability, both through a direct relationship (Hypothesis H2a) and through an indirect effect of ambition and protean career orientation (Hypothesis H2b).

\section{Materials and Methods}

\subsection{Participants}

Data were collected as part of a guidance project carried out at a training institution in northern Italy. Participants were unemployed subjects who had requested individual counselling for job searching; in particular, a self-report questionnaire was administered by researchers to the unemployed people during the first career counselling meeting.

The research team presented the aims of the project, explained the data collection procedures, and specified that there would be no potential risk or cost involved. The questionnaire included a statement on personal data protection, in accordance with Italian Legislative Decree 196/2003.

The final sample consisted of 228 unemployed individuals. Most of these (56.64\%) were women, and the mean age was 25.45 ( $\mathrm{SD}=7.50$ ). Fifteen $(6.58 \%)$ participants had secondary education, one hundred fifty-eight (69.3\%) held a high school degree, forty-four (19.3\%) participants were university graduates, and eleven $(4.82 \%)$ had a post-graduate degree.

On average, they had been unemployed for 8.39 months $(\mathrm{SD}=15.57)$ and had been looking for a job for 6 months $(S D=13.73)$. 


\subsection{Measures}

Emotion regulation was measured with ten items taken from the scale developed by Balzarotti, John, and Gross [66], which measures Cognitive Reappraisal (6 items) and expressive Suppression (4 items). With regards to the first dimension, which consisted of attempting to think about a situation so as to alter its meaning and emotional impact, respondents had to indicate their agreement with items such as 'When I want to feel more positive emotion (i.e., joy or amusement), I change what I'm thinking about'. Concerning the expressive suppression dimension, which consisted of attempting to inhibit or reduce ongoing emotion expressive behaviour, participants had to indicate their agreement with items such as 'I keep my emotions to myself'. The response format consisted of a 6-point 'Likert scale ranging from 1 (not at all) to 6 (very much).

Cronbach's alpha for the subscale of Cognitive Reappraisal was $\alpha=0.86$; Cronbach's alpha for the subscale of Expressive Suppression was $\alpha=0.77$. Reappraisal and suppression were two independent emotional strategies that each individual applied to varying levels with resulting differences in related measures of coping strategies [67]. Consequently, a single indicator of emotion regulation (EG) was calculated by subtracting the average of expressive suppression dimension from the average of the cognitive reappraisal. A high degree of emotion regulation (EG) indicated a more predominant use of cognitive reappraisal than suppression.

Career Ambition (CA) was measured with six items that were adapted from the scale developed by Rothwell, Jewell, and Hardie [47]. Respondents had to indicate their agreement with items such as 'I want to be in a position to do mostly the work that I like'. The response format consisted of a 6-point 'Likert scale ranging from 1 (not at all) to 6 (very much).

The reliability of the scale was $\alpha=0.64$.

Protean career orientation was measured with seven items from the short version of the scale developed by Baruch [68]. Respondents had to indicate their agreement with items such as 'For me, career success is how I am doing against my goals and values' or 'If I had to find a new job, it would be easy'. All items were scored on a 6-point Likert scale ranging from 1 (not at all) to 6 (very much). Cronbach's alpha for the scale was $\alpha=0.73$.

Employability was assessed with five items which were adapted from the scale developed by Berntson and Marklun [69]. Respondents were asked to indicate their agreement with items such as 'My degree is requested in the labour market'. All items were scored on a 6-point Likert scale ranging from 1 (not at all) to 6 (very much). The internal consistency of the scale, measured with Cronbach's Alpha coefficient, was $\alpha=0.68$.

\section{Data Analysis}

First, Cronbach's alpha for the reliability of the scales was calculated. We considered that composite reliability values of 0.60 to 0.70 are acceptable in exploratory research [70,71]. Secondly, preliminary analysis was carried out on the descriptive statistics.

Thirdly, analyses of the relationship between emotion regulation, ambition, protean career orientation, and perceived employability were carried out using Pearson's correlation coefficient. Finally, the serial multivariate mediation analysis was conducted to examine a mediating model of these four variables. This analysis allows for an independent variable (IV), a dependent variable (DV), and two simultaneous mediators variables to be included (MV1 and MV2). In this model we hypothesized that emotion regulation (IV) influenced the perceived employability (DV), through causally linked multiple mediators of the ambition (MV1) and protean career orientation (MV2).

As shown in Figure 1, Ambition (MV1) and protean career orientation (MV2) were used as mediators explaining the pathways from emotion regulation to perceived employability. The total, direct and indirect effects were estimated by the SPSS PROCESS macro (model 6). A total effect (c) refers to the relationship between the IV and DV without controlling for the MVs. A direct effect $\left(c^{\prime}\right)$ refers to the relationship between the IV and DV after controlling for the MVs (ambition and protean 
career orientation). The indirect effects for the serial multiple mediation analysis were the effects of the IV on the DV through the MV1 or through the MV2, or through both the MV1 and the MV2.

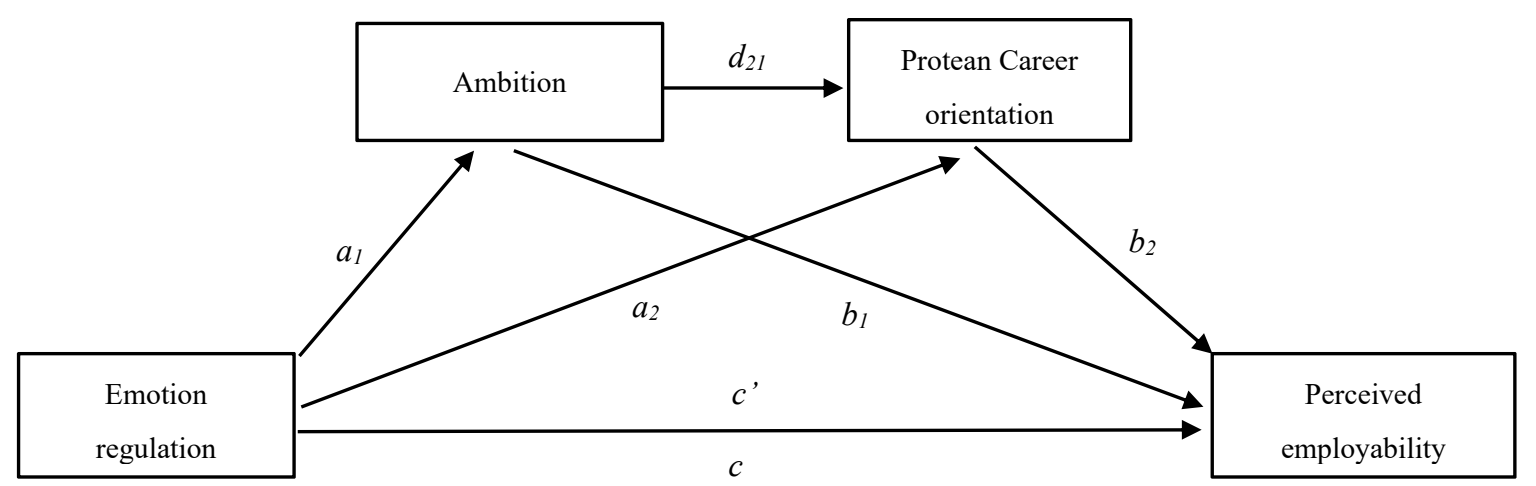

Figure 1. The hypothesized serial mediation model.

The Figure 1, that describes the model 6, also shows the direct effect of Emotion Regulation (IV) on the first mediator $\left(\mathrm{a}_{1}\right)$ and second mediator $\left(\mathrm{a}_{2}\right)$. Furthermore, the direct effects of Ambition, respectively, on Protean on Career Orientation $\left(\mathrm{d}_{21}\right)$ and Perceived Employability (b1), are represented $\left(\mathrm{b}_{1}\right)$. Finally, the Figure 1 shows the direct effect of Protean Career Orientation on the dependent variable $\left(b_{2}\right)$.

A $95 \%$ confidence interval (CI) was calculated with 10,000 bootstrapping re-samples. If the $95 \%$ $\mathrm{CI}$ of the mediation path did not contain 0 , the indirect effect was considered statistically significant.

Since some factors can produce spurious associations in an almost nonexperimental study, such as this research, age, gender, and months of job search were introduced as covariates.

\subsection{Descriptive Results}

The means, standard deviations, internal consistencies, and correlations were computed for all study variables, as reported in Table 1. Internal consistency (Cronbach's alpha) for all variables ranged between $\alpha=0.64$ and $\alpha=0.81$. All significant relationships between the variables were in the expected direction. Emotion regulation was positively related to ambition $(\mathrm{r}=0.34 ; p<0.001)$, to protean career orientation $(\mathrm{r}=0.26 ; p<0.001)$, and perceived employability $(\mathrm{r}=0.18 ; p<0.01)$. Ambition related positively with protean career orientation $(\mathrm{r}=0.51 ; p<0.001)$ and employability $(\mathrm{r}=0.32 ; p<0.001)$. Furthermore, protean career orientation was positively correlated to perceived employability $(r=0.42$; $p<0.001$ ). According to hypothesis 1 , the perception of employability is strictly related to the emotion regulation, perception of ambition and protean career orientation in this sample of unemployed people.

Table 1. Means, standard deviations, Cronbach's alpha (along the diagonal) and correlations among study variables $(\mathrm{N}=228)$.

\begin{tabular}{llccccccc}
\hline & \multirow{2}{*}{ Variable } & Range & $\mathbf{M}$ & SD & \multicolumn{4}{c}{$\mathbf{R}$} \\
\cline { 7 - 9 } & & & & & $\mathbf{1}$ & $\mathbf{2}$ & $\mathbf{3}$ & $\mathbf{4}$ \\
\hline 1. & Emotion Regulation & 1 & $-5-5$ & 1.12 & 1.37 & & & \\
2. & Ambition & $1-6$ & 4.90 & 0.63 & $0.34^{* * *}$ & $(0.64)$ & & \\
3. & Protean Career & $1-6$ & 4.29 & 0.78 & $0.26^{* * *}$ & $0.51^{* *}$ & $(0.73)$ & \\
4. & Employability & $1-6$ & 3.45 & 0.68 & $0.19^{* *}$ & $0.32^{* *}$ & $0.42^{* *}$ & $(0.68)$ \\
\hline
\end{tabular}

Note: ${ }^{1}$ Emotion regulation is calculated subtracting the average expressive suppression dimension from the average cognitive reappraisal component; ${ }^{* *} p<0.01 ;{ }^{* * *} p<0.001 . \mathrm{M}=$ Mean; $\mathrm{SD}=$ Standard Deviation.

\subsection{Serial Mediation Model}

The results of the mediation analysis showed that emotion regulation, ambition and protean career orientation explained the $49 \%$ of variance of perceived employability $\left(\mathrm{R}_{2}=0.239, \mathrm{~F}=10.90, p \leq 0.001\right)$. 
Figure 2 displays the relationship among emotion regulation, ambition, protean career orientation, and perceived employability. The emotion regulation (ER) has not a direct effect on perceived employability (PE) after controlling for ambition and protean career orientation (PCO) $(b=0.06$, $\mathrm{SE}=0.038, p=0.08 ; 95 \% \mathrm{CI}[-0.009 ; 0.141], \beta=0.11)$, but he total indirect effect of ER on PE was significant $(\mathrm{b}=0.08, \mathrm{SE}=0.038, p \leq 0.001,95 \% \mathrm{CI}$ [0.069; 0.221], $\beta=0.15)$. Therefore, the relationship between emotion regulation and perceived employability was totally mediated by ambition (A) and protean career orientation (PCO). The hypothesis $\mathrm{H} 2 \mathrm{~b}$ was confirmed.

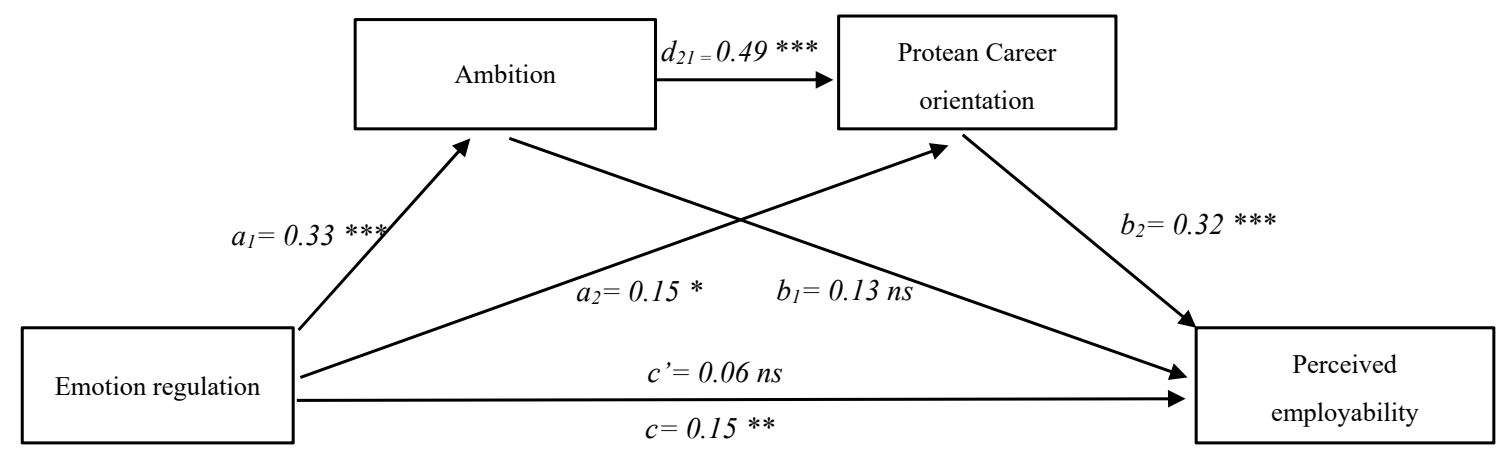

Note. ${ }^{*} p<0.05 ; * * 0<0.01 ; * * * 00.001$.

Figure 2. Relationship between emotion regulation, ambition, protean career orientation, and perceived employability.

The analysis also shows that emotion regulation had a significant impact on ambition $(b=0.15$, $\mathrm{SE}=0.030, p=\leq 0.0001, \beta=0.33)$ and protean career orientation $(\mathrm{b}=0.07, \mathrm{SE}=0.031, p \leq 0.05, \beta=0.15)$. Ambition was significantly associated with PCO $(b=0.54, \mathrm{SE}=0.068, p \leq 0.0001, \beta=0.33)$. Protean career orientation had a direct effect on $\mathrm{PE}(\mathrm{b}=0.36, \mathrm{SE}=0.083, p \leq 0.0001, \beta=0.32)$ while ambition has not a direct effect on PE $(b=0.15, \mathrm{SE}=0.093, p=0.099, \beta=0.12)$.

The indirect effect of ER on PE through PCO was significant $(b=0.03, \mathrm{SE}=0.011, p \leq 0.001,95 \% \mathrm{CI}$ [0.006; 0.050], $\beta=0.05)$. However, the indirect effect of emotion regulation on PE through ambition was not significant $(b=0.02, \mathrm{SE}=0.015, p \leq 0.001,95 \% \mathrm{CI}[-0.003 ; 0.055], \beta=0.04)$.

\section{Discussion}

The current study aimed to explore whether career ambition and protean career orientation played a role in mediating the relationship between emotion regulation and perceived employability. A serial mediating model revealed the complex pathway in which the perception of employability among unemployed people was determined by their emotional strategies, career ambition and proactive attitudes towards career.

Particularly, the obtained results showed that there was an association between emotion strategies and perceived employability. This was in line with recent researches showing that one's abilities to rework one's emotional experience in connection with one's state of unemployment reinforce one's perception of having control over challenging situations and having employable skills, with a positive impact on job search strategies $[27,29]$.

On the other hand, the current results indicated that there was no direct effect of emotion regulation on perceived employability. The effect was indirect and totally mediated by career ambition and protean career orientation, thus confirming the third hypothesis. This result was consistent with previous literature pointing out that self-realization and the likelihood of not losing one's future prospects inherent one's career ambitions stimulated proactivity, and such an attitude was a precursor of perceived employability [16,35].

The strength of the relationship between career ambition and protean career orientation was particularly high, suggesting that establishing clear career goals was an essential factor of proactive 
career planning [72] and people characterized by a strong protean career orientation were likely to define their career goals in a way that would enable them to fulfil their values [55]. In fact, the efforts to bring out unemployed people's personal ambitions stimulated in them a proactive orientation that helped them to alter the job situations to suit their own needs, reducing the anxiety and uncertainty inherent the external labour market.

Furthermore, the study revealed that a protean career attitude was significantly associated with the perception of being employable, a crucial aspect that could lead unemployed individuals to consider new alternatives in the labour market and to be motivated to engage in job search using job loss as a possibility to choose new career goals [59]. Individuals with a high level of protean career orientation had a clear vision of what they wanted to pursue in their career, possessed a strong sense of agency about their ability to manage career-related challenges while exploring the sectors of the labour market where their skills were more attractive.

These results suggested that emotion management is pivotal in triggering a motivational process that allowed unemployed people to reinterpret their negative condition. Particularly, individuals who used more cognitive reappraisal strategies than suppression were more likely to face stressful events, because they saw themselves in a new light, which in turn decreased the individuals' negative emotions. This strategy had a positive effect as it helped unemployed people to reflect on their professional goals and to define suitable plans for reaching such goals, taking personal responsibility for their self-realization. People who applied functional emotion regulation strategies also had greater opportunities to explore job alternatives in a realistic way, given their tendency to be more proactive in collecting information, increasing personal skills, and defining a way to reach their goals. These strategies contributed to shaping a high and realistic level of employability, to identifying professional competencies they possessed, and to adapting to the context, thus creating future career plans not imagined before.

\section{Limitation}

The current study had several limitations that should be taken into account. First of all, only self-report measures were used. Therefore, we could not rule out the effect of shared method bias that might have magnified the observed relationships among the variables. Secondly, there was the aspect connected with the cross-sectional nature of the study. This restricted the confirmation of the causality between the measures. Thirdly, the research did not consider socio-economic aspects that could have had an impact on analyzed variables, such as family income. An interesting avenue for future research entails the investigation the role of emotion regulation in career decision-making process: emotion regulation affects the general decision making process, for example the individual experience of anger [73], which is a widespread feeling in unemployed people. Longitudinal studies should also investigate the impact of emotion regulation in the effective re-employment in the labor market and consequent outcomes, as job satisfaction or organizational socialization.

\section{Conclusions}

Despite the limitations outlined above, this study provided important new insights into the relation of emotion regulation to employability, identifying some processes that could help unemployed people to explore new career goals and paths, whilst considering new alternatives and enhancing strengths and skills.

If unemployed people have the ability to better manage their emotional experience, they will be able to perceive personal skills and ambitions as internal strengths and, consequently, to identify new professional goals and pathways that will lead them to find sectors in the labor market where they could be employed. Furthermore, recent research on career adaptability suggested that adequate strategies of emotion regulation support individuals' capacity to prepare for an uncertain and changing job market [74]. 
This research implied that helping to use cognitive strategies allowing one to re-interpret one's situation differently, so to better cope with the difficulties associated with unemployment and to avoid processes of suppression of negative emotion, could enhance one's control over one's career path, leading to the perception of better employability and best strategies for exploring the labor market. A similar deduction was found in recent research [74], which affirmed that emotion regulation influences how workers process information and make judgments that should influence career planning and career decision-making. In this sense, counsellors working with unemployed clients should focus on building positive perspectives in connection with their clients' career goals and sense of self direction and agency. When these two aspects of PCO are adopted, employability is more effectively utilized with respect to job searching. These counselling interventions should help unemployed people to be aware of their goals, expectations, technical and soft skills, and may guide them in developing proactive career strategies, in order to enhance their employability [75].

Unemployed clients can also be encouraged to actively promote their career ambition by having a strong focus on their professional life, regardless of their unemployment situation. This broader view can help to maintain a positive sense of identity and psychological success despite one being out of work.

Since the labour market is constantly changing, it is necessary to strengthen counselling functions, especially networking, in order to provide the kind of support that promotes proactivity and the ability to face the different transitions that can occur in anyone's professional life.

Author Contributions: Conceptualization, M.T., C.P. and G.M.; Formal analysis, M.T. Investigation, M.T. and C.P.; writing-original draft preparation, M.T.; writing-review, C.P. and G.M. All authors have read and agreed to the published version of the manuscript.

Funding: This research received no external funding.

Conflicts of Interest: The authors declare no conflict of interest.

\section{References}

1. Hodzic, S.; Ripoll, P.; Lira, E.; Zenasni, F. Can Intervention in Emotional Competences Increase Employability Prospects of Unemployed Adults? J. Vocat. Behav. 2015, 88, 28-37. [CrossRef]

2. Hooghe, M.; Vanhoutte, B.; Hardyns, W.; Bircan, T. Unemployment, inequality, poverty and crime: Spatial distribution patterns of criminal acts in belgium, 2001-2006. Br. J. Criminol. 2011, 51, 1-20. [CrossRef]

3. McKee-Ryan, F.; Song, Z.; Wanberg, C.R.; Kinicki, A.J. Psychological and physical well-being during unemployment: A meta-analytic study. J. Appl. Psychol. 2015, 90, 53-76. [CrossRef]

4. Wanberg, C.R. The Individual Experience of Unemployment. Annu. Rev. Psychol. 2012, 63, 369-396. [CrossRef]

5. Paul, K.I.; Moser, K. Unemployment impairs mental health: Meta-analyses. J. Vocat. Behav. 2009, 74, $264-282$. [CrossRef]

6. Graversen, B.K.; Van Ours, J.C. Activating unemployed workers works; experimental evidence from Denmark. Econ. Lett. 2008, 100, 308-310. [CrossRef]

7. Petrongolo, B. The long-term effects of job search requirements: Evidence from the UK JSA reform. J. Public Econ. 2009, 93, 1234-1253. [CrossRef]

8. Ferraro, A.; Guarnaccia, C.; Infurna, M.; Amato, L.; Nicotra, M.; Giannone, F. Postmodernity, insecurity and job loss Focus on the unemployed's suffering. J. Psychopathol. 2017, 23, 145-153.

9. Koen, J.; Klehe, U.; Van Vianen, A.E.M. Employability among the long-term unemployed: A futile quest or worth the effort? J. Vocat. Behav. 2013, 82, 37-48. [CrossRef]

10. Van der Heijden, B.I.J.M. The development and psychometric evaluation of a multi-dimensional measurement instrument of professional expertise. High Abil. Stud. J. Eur. Counc. High Abil. 2000, 11, 9-39.

11. De Vos, A.; De Hauw, S.; Van der Heijden, B.I.J.M. Competency development and career success: The mediating role of employability. J. Vocat. Behav. 2011, 79, 438-447. [CrossRef]

12. Audenaert, M.; Van der Heijden, B.; Conway, N.; Crucke, S.; Decramer, A. Vulnerable workers' employability competences: The role of establishing clear expectations, developmental inducements, and social organizational goals. J. Bus. Ethics 2019, 166, 627-641. [CrossRef] 
13. Vinokur, A.D.; Schul, Y.; Vuori, J.; Price, R.H. Two years after a job loss: Long-term impact of the JOBS program on reemployment and mental health. J. Occup. Health Psychol. 2000, 5, 32-47. [CrossRef]

14. Vuori, J.; Vinokur, A.D. Job-search preparedness as a mediator of the effects of the työhön job search intervention on re-employment and mental health. J. Organ. Behav. 2005, 26, 275-291. [CrossRef]

15. Tay, C.; Ang, S.; Van Dyne, L. Personality, biographical characteristics, and job interview success: A longitudinal study of the mediating effects of interviewing self-efficacy and the moderating effects of internal locus of causality. J. Appl. Psychol. 2006, 91, 446-454. [CrossRef]

16. Urquijo, I.; Extremera, N.; Solabarrieta, J. Connecting Emotion Regulation to Career Outcomes: Do Proactivity and Job Search Self-Efficacy Mediate This Link? Psychol. Res. Behav. Manag. 2020, 12, 1109. [CrossRef]

17. Wang, L.; Yan, F. Emotion regulation strategy mediates the relationship between goal orientation and job search behavior among university seniors. J. Vocat. Behav. 2018, 108, 1-12. [CrossRef]

18. Brockman, R.; Ciarrochi, J.; Parker, P.; Kashdan, T. Emotion regulation strategies in daily life: Mindfulness, cognitive reappraisal and emotion suppression. Cogn. Behav. Ther. 2017, 46, 91-113. [CrossRef]

19. Gross, J.J. Emotion regulation in adulthood: Timing is everything. Curr. Dir. Psychol. Sci. 2001, 10, $214-219$. [CrossRef]

20. Gross, J.J. Antecedent- and response-focused emotion regulation: Divergent consequences for experience, expression, and physiology. J. Personal. Soc. Psychol. 1998, 74, 224-237. [CrossRef]

21. Wolgast, M.; Lundh, L.; Viborg, G. Cognitive reappraisal and acceptance: An experimental comparison of two emotion regulation strategies. Behav. Res. Ther. 2011, 49, 858-866. [CrossRef]

22. Hu, T.Q.; Zhang, D.J.; Wang, J.L.; Mistry, R.; Ran, G.M.; Wang, X.Q. Relation between emotion regulation and mental health: A meta-analysis review. Psychol. Rep. 2014, 114, 341-362. [CrossRef]

23. Llewellyn, N.; Dolcos, S.; Iordan, A.D.; Rudolph, K.D.; Dolcos, F. Reappraisal and suppression mediate the contribution of regulatory focus to anxiety in healthy adults. Emotion 2013, 13, 610-615. [CrossRef]

24. Blanco-Donoso, L.M.; Garrosa, E.; Demerouti, E.; Moreno-Jiménez, B. Job resources and recovery experiences to face difficulties in emotion regulation at work: A diary study among nurses. Int. J. Stress Manag. 2017, 24, 107-134. [CrossRef]

25. Huang, H.; Liu, L.; Yang, S.; Cui, X.; Zhang, J.; Wu, H. Effects of job conditions, occupational stress, and emotional intelligence on chronic fatigue among Chinese nurses: A cross-sectional study. Psychol. Res. Behav. Manag. 2019, 12, 351. [CrossRef]

26. Mérida-López, S.; Extremera, N.; Rey, L. Emotion-regulation ability, role stress and teachers' mental health. Occup. Med. 2017, 67, 540-545. [CrossRef]

27. Peláez-Fernández, A.M.; Rey, L.; Extremera, N. Psychological distress among the unemployed: Do core self-evaluations and emotional intelligence help to minimize the psychological costs of unemployment? J. Affect. Disord. 2019, 256, 627-632. [CrossRef]

28. Brief, A.P.; Weiss, H.M. Organizational behavior: Affect in the workplace. Annu. Rev. Psychol. 2002, 53, 279-307. [CrossRef]

29. Rode, J.C.; Arthaud-Day, M.; Ramaswami, A.; Howes, S. A time-lagged study of emotional intelligence and salary. J. Vocat. Behav. 2017, 101, 77-89. [CrossRef]

30. Sjöberg, L. CHAPTER 10: Emotional Intelligence and Life Adjustment. Counterpoints 2008, 336, 169-183.

31. Callea, A.; Urbini, F.; Ingusci, E.; Chirumbolo, A. The relationship between contract type and job satisfaction in a mediated moderation model: The role of job insecurity and psychological contract violation. Econ. Ind. Democr. 2016, 37, 399-420. [CrossRef]

32. Brackett, M.A.; Rivers, S.E.; Salovey, P. Emotional intelligence: Implications for personal, social, academic, and workplace success. Soc. Personal. Psychol. Compass 2011, 5, 88-103. [CrossRef]

33. Berntson, E.; Näswall, K.; Sverke, M. Investigating the relationship between employability and self-efficacy: A cross-lagged analysis. Eur. J. Work Organ. Psychol. 2008, 17, 413-425. [CrossRef]

34. Vanhercke, D.; De Cuyper, N.; Peeters, E.; De Witte, H. Defining perceived employability: A psychological approach. Pers. Rev. 2014, 43, 592-605. [CrossRef]

35. De Vos, A.; Soens, N. Protean attitude and career success: The mediating role of self management. J. Vocat. Behav. 2008, 73, 449-456. [CrossRef]

36. Van den Broeck, A.; Vansteenkiste, M.; Lens, W.; De Witte, H. Unemployed individuals' work values and job flexibility: An explanation from expectancy value theory and self-determination theory. Appl. Psychol. Int. Rev. 2010, 59, 296-317. [CrossRef] 
37. Fugate, M.; Kinicki, A.J.; Ashforth, B.E. Employability: A psycho-social construct, its dimensions, and applications. J. Vocat. Behav. 2004, 65, 14-38. [CrossRef]

38. Climent-Rodríguez, J.A.; Navarro-Abal, Y.; López-López, M.J.; Gómez-Salgado, J.; García, M.E.A. Grieving for Job Loss and Its Relation to the Employability of Older Jobseekers. Front. Psychol. 2019, 10, 366. [CrossRef]

39. Wang, L.; Xu, H.; Zhang, X.; Fang, P. The relationship between emotion regulation strategies and job search behavior among fourth-year university students. J. Adolesc. 2017, 59, 139-147. [CrossRef]

40. Alonso-García, M.A. Evaluación del potencial de inserción laboral y patrones de carrera. Rev. De Educ. 2010, 351, 409-434.

41. Jackson, D.; Tomlinson, M. Career values and proactive career behaviour among contemporary higher education students. J. Educ. Work 2019, 32, 449-464. [CrossRef]

42. Aybas, M.; Kurbaslar, M. The effect of ambition, internal locus of control and innovativeness on self-perceived employability. Res. J. Bus. Manag. 2014, 1, 353-364.

43. Ćurić Dražić, M.; Petrović, I.B.; Vukelić, M. Career ambition as a way of understanding the relation between locus of control and self-perceived employability among psychology students. Front. Psychol. 2018, 9, 1729. [CrossRef]

44. Zafar, J.; Farooq, M.; Quddoos, M.U. The relationship between protean career orientation and perceived employability: A study of private sector academics of Pakistan. J. Manag. Sci. 2017, 4, 133-145. [CrossRef]

45. Donald, W.E.; Baruch, Y.; Ashleigh, M. The undergraduate self-perception of employability: Human capital, careers advice, and career ownership. Stud. High. Educ. 2019, 44, 599-614. [CrossRef]

46. Cortellazzo, L.; Bonesso, S.; Gerli, F.; Batista-Foguet, J.M. Protean career orientation: Behavioral antecedents and employability outcomes. J. Vocat. Behav. 2020, 116, 103343. [CrossRef]

47. Rothwell, A.; Jewell, S.; Hardie, M. Self-perceived employability: Investigating the responses of post-graduate students. J. Vocat. Behav. 2009, 75, 152-161. [CrossRef]

48. Elchardus, M.; Smits, W. The vanishing flexible: Ambition, self-realization and flexibility in the career perspectives of young Belgian adults. Work. Soc. 2008, 22, 243-262. [CrossRef]

49. Otto, K.; Roe, R.; Sobiraj, S.; Baluku, M.M.; Vásquez, M.E.G. The impact of career ambition on psychologists' extrinsic and intrinsic career success. Career Dev. Int. 2016, 22, 23-36. [CrossRef]

50. Crant, J.M. Proactive Behavior in Organizations. J. Manag. 2000, 26, 435-462. [CrossRef]

51. Brown, D.J.; Cober, R.T.; Kane, K.; Levy, P.E.; Shalhoop, J. Proactive personality and the successful job search: A field investigation with college graduates. J. Appl. Psychol. 2006, 91, 717-726. [CrossRef]

52. Zacher, H.; Bock, A. Mature age job seekers: The role of proactivity. J. Manag. Psychol. 2014, 29, $1082-1097$. [CrossRef]

53. Bao, Z.; Luo, P. How college students' job search self-efficacy and clarity affect job search activities. Soc. Behav. Personal. Int. J. 2016, 44, 39-51. [CrossRef]

54. Zampetakis, L.A.; Kafetsios, K.; Bouranta, N.; Dewett, T.; Moustakis, V.S. On the relationship between emotional intelligence and entrepreneurial attitudes and intentions. Int. J. Entrep. Behav. Res. 2009, 15, 595-618. [CrossRef]

55. Hall, D.T. Careers in Organizations; Scott Foresman: Glenview, IL, USA, 1976.

56. Briscoe, J.P.; Hall, D.T. The interplay of boundaryless and protean careers: Combinations and implications. J. Vocat. Behav. 2006, 69, 4-18. [CrossRef]

57. Arthur, M.B.; Khapova, S.N.; Wilderom, C.P. Career success in a boundaryless career world. J. Organ. Behav. Int. J. Ind. Occup. Organ. Psychol. Behav. 2005, 26, 177-202. [CrossRef]

58. Reitman, F.; Schneer, J.A. Enabling the new careers of the 21st century. Organ. Manag. J. 2008, 5, 17-28. [CrossRef]

59. Bedwell, W.L.; Fiore, S.M.; Salas, E. Developing the future workforce: An approach for integrating interpersonal skills into the MBA classroom. Acad. Manag. Learn. Educ. 2014, 13, 171-186. [CrossRef]

60. Waters, L.; Briscoe, J.; Hall, D.T. Using protean career attitude to facilitate a positive approach to unemployment. In Psycho-Social Career Meta-Capacities; Springer: Cham, Switzerland, 2014; pp. 19-33.

61. Jafri, M.H.; Dem, C.; Choden, S. Emotional intelligence and employee creativity: Moderating role of proactive personality and organizational climate. Bus. Perspect. Res. 2016, 4, 54-66. [CrossRef]

62. Chi, S.C.S.; Liang, S.G. When do subordinates' emotion-regulation strategies matter? Abusive supervision, subordinates' emotional exhaustion, and work withdrawal. Leadersh. Q. 2013, 24, 125-137. [CrossRef] 
63. Lee, K.H.; Song, J.S. The effect of emotional intelligence on self-efficacy and job stress of nurses-mediating role of self-efficacy. J. Korean Acad. Nurs. Adm. 2010, 16, 17. [CrossRef]

64. Alshebami, A.S.; Alamri, M.M. The Role of Emotional Intelligence in Enhancing the Ambition Level of the Students: Mediating Role of Students' Commitment to University. J. Talent Dev. Excell. 2020, 12, 2275-2287.

65. Rahim, N.B.; Siti-Rohaida, M.Z. Protean career orientation and career goal development: Do they predict engineer's psychological well-being. Procedia Soc. Behav. Sci. 2015, 172, 270-277. [CrossRef]

66. Balzarotti, S.; John, O.P.; Gross, J.J. An Italian adaptation of the emotion regulation questionnaire. Eur. J. Psychol. Assess. 2010, 26, 61-67. [CrossRef]

67. John, O.P.; Gross, J.J. Healthy and unhealthy emotion regulation: Personality processes, individual differences, and life span development. J. Personal. 2004, 72, 1301-1334. [CrossRef]

68. Baruch, Y. The development and validation of a measure for protean career orientation. Int. J. Hum. Resour. Manag. 2014, 25, 2702-2723. [CrossRef]

69. Berntson, E.; Marklund, S. The relationship between perceived employability and subsequent health. Work Stress 2007, 21, 279-292. [CrossRef]

70. Creswell, J.W. Educational Research: Planning, Conducting, and Evaluating Quantitative; Prentice Hall: Upper Saddle River, NJ, USA, 2002; pp. 146-166.

71. Nunnally, J.C.; Bernstein, I.R. Psychometric Theory; Oxford University: New York, NY, USA, 1994.

72. Abele, A.E.; Wiese, B.S. The nomological network of self-management strategies and career success. J. Occup. Organ. Psychol. 2008, 81, 733-749. [CrossRef]

73. Zaki, J. Integrating empathy and interpersonal emotion regulation. Annu. Rev. Psychol. 2020, 71, 517-540. [CrossRef]

74. Restubog, S.L.D.; Ocampo, A.C.G.; Wang, L. Taking control amidst the chaos: Emotion regulation during the COVID-19 pandemic. J. Vocat. Behav. 2020, 119, 103440. [CrossRef]

75. Chiesa, R.; Van der Heijden, B.I.; Mazzetti, G.; Mariani, M.G.; Guglielmi, D. "It Is All in the Game!”: The Role of Political Skill for Perceived Employability Enhancement. J. Career Dev. 2020, 47, 394-407. [CrossRef]

Publisher's Note: MDPI stays neutral with regard to jurisdictional claims in published maps and institutional affiliations.

(C) 2020 by the authors. Licensee MDPI, Basel, Switzerland. This article is an open access article distributed under the terms and conditions of the Creative Commons Attribution (CC BY) license (http://creativecommons.org/licenses/by/4.0/). 